\title{
Uusien oppimisympäristöjen representaatiot oppimisen välineinä
}

\author{
Jarmo Levonen
}

\begin{abstract}
Oppiminen ja opiskelu uusissa oppimisympäristöissä voi olla hyvin monimuotoista. Oppija voi perehtyä sisältöalueeseen, suorittaa harjoituksia, seurata ja osallistua keskusteluun, hän voi suunnitella ja arvioida tai osallistua muuten aktiivisesti virtuaalisen oppimisyhteisön toimintaan. Salomon (1991) esittää kaksi eri näkökulmaa: millainen vaikutus oppimiseen on työskentelyllä teknologian kanssa ('with'), sekä toisaalta miten opitaan teknologian vaikutuksesta ('of') .
\end{abstract}

$\mathrm{U}$ usien $^{1}$ oppimisympäristöjen ${ }^{2}$, kuten verk$\mathrm{ko}^{3}$ - teknologiaa hyödyntävien oppimisympäristöjen kehittyminen ja toisaalta ympäristöjen käyttöä tukevien pedagogisten käytäntöjen muodostuminen on tuonut sekä mahdollisuuksia että uusia haasteita oppimisen kehittämiselle ja tutkimukselle. Uusia oppimisympäristöjä ja erityisesti verkko-perustaisten oppimisympäristöjen etäkäyttömahdollisuuksia hyödyntäen voidaan pyrkiä kehittämään esimerkiksi opetuksen joustavia toteutusmalleja: Kurssienjärjestelyistä voidaan tiedottaa verkossa ja ilmoittautumiset, peruutukset ja muut hallinnolliset toimenpiteet voi toteuttaa kurssit yhdistävässä "opiskeluportaali"-verkkosivulla; opiskelijoiden, ryhmien ja opettajien välinen ja keskinäinen kommunikaatio voidaan organisoida monipuolisesti; luennot ja opettajan esitykset on palautettavissa editoituina koosteina, joihin on lisätty esimerkiksi luennon kalvot, lisätietoja aiheesta ja muuta oheismateriaalia; omaehtoista opiskeluaja harjoittelua voi suorittaa ennen kurssia, kurssin kuluessa tai muina aikoina käyttäen esimerkiksi aiheeseen perehdyttäviä tutoriaaleja, ohjattuja kertaustehtäviä tai opetusohjelmia; kollaboratiivisia projekteja voidaan toteuttaa kurssin opetuksen ja arvioinnin tukena; arviointia voidaan kehittää ja monipuolistaa esimerkiksi käyttämällä verkkoa itsearvioinnin tai vertaisarvioinnin välineenä; ja muut opetuksen järjestelyt, kuten kirjasto-, opiskelun ohjaus- tai opetusteknologiapalvelut voidaan toteuttaa joustavasti hyödyntämällä uusien tietoverkkojen ja oppimisympäristöjen tarjoamia mahdollisuuksia (Collis 2000).

Suomessa opetuksen joustavia järjestelyjä on pyritty kehittämään ja toteuttamaan käyttämällä kaupallisesti saatavilla olevia oppimisympäristöjä (esimerkiksi WebCT ${ }^{4}$ ja Learning Space ${ }^{5}$ ), hyödyntämällä työryhmäohjelmistoja (esimerkiksi 
Lotus Notes $^{6}$ ja FirstClass ${ }^{7}$ ), soveltamalla opetuksessa Internetistä löytyviä sovelluksia (esimerkiksi WWWBoard ${ }^{8}$ ja HyperNews ${ }^{9}$ ) tai kehittämällä paikallinen oppimisympäristö, jolla voidaan kehittää joustavia opetusratkaisuja ja tutkia oppimista ja opetusta uudessa oppimisympäristössä, (esimerkiksi ThULE ${ }^{10}$, PROTO $^{11}$, FLE $^{12}$ ja Workmates ${ }^{13}$ ympäristöt). (Hietala, Majaranta, Niemirepo, Ovaska, \& Salonen 1997; Levonen \& Tuononen 1998, Huhtikuu; Sinko \& Lehtinen 1998).

Opetuksen ja oppimisen uusien mediaympäristöjen "ilosanomaan" on kuitenkin suhtauduttava kriittisesti. Viimeaikainen mediaympäristöjen kehitys on osoittanut, että vaikka mediaympäristöt tuovat mahdollisuuksia uudistaa oppimista ja opetusta niin samanaikaisesti mediaympäristöihin ja niiden "markkinointiin " liittyy myyttejä ja virheellisiä käsityksiä ja odotuksia (Dillon 1996; Rouet \& Levonen 1996). Voidaankin kysyä, mikä erottaa yhden oppimisympäristön toisesta? Millaista oppimista ja/tai opetusta tietyssä oppimisympäristössä tuetaan? Eräs tärkeä näkökulma on pohtia, miten oppimisympäristön ja oppijan välinen ${ }^{14}$ vuorovaikutus on organisoitu: Millaisia kognitiivisia, sosiaalisia, situationaalisia ym. oppimisen "välineitä" (eli miten ympäristössä osallistutaan ja miten kommunikoidaan) ko. oppimisympäristö tarjoaa oppijalle ja miten nämä "välineet" on edustettu ${ }^{15}$ ko. oppimisympäristössä (eli miten tietoa, toimintaa, tavoitteita, jne. edustetaan kuvin, ohjein, tehtävien ja toimintojen avulla ko. oppimisympäristössä)?

Artikkelissa tarkastellaan ensin oppimista kognitiivisten ja moninaisten representaatioiden näkökulmasta, sitten käsitellään uusien oppimisympäristöjen herättämiä kysymyksiä ja lopuksi tarkastellaan, minne käynnissä oleva oppimisympäristöjen kehittyminen näyttää olevan suuntaamassa.

\section{Representaatiot ja uudet verkko-oppimisympäristöt}

Oppimisympäristössä kommunikointia ja vuorovaikutusta voidaan toteuttaa käyttäen ko.

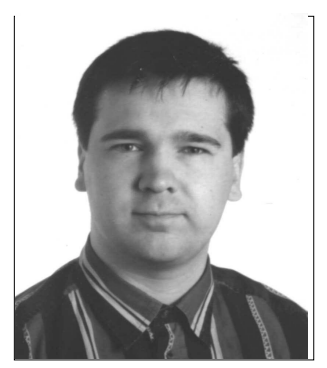

Jarmo Levonen

ympäristön moninaisia (tai multiplekseja ${ }^{16}$ ) representaatiota, kuten kuvia, tekstejä, tehtäviä jne., jotka kuvaavat esimerkiksi HyperNews verkkokeskustelun etenemistä (viestit on allekkain), kommentoinnin syvyystasoa (viestit on sisennetty), viestien luonnetta (viestiin on liitetty ikoninen kuva, kuten kysymysmerkki, sormi ylös tai alas, huutomerkki, puhekupla jne., kuvaamaan viestin luonnetta), viestien aiheita (viestien otsikot) (Levonen, Tuononen, \& Laine 1997, November). Vastaavasti toisenlaisessa ympäristössä moninaiset representaatiot voivat kuvata ko. ympäristön erityisiä piirteitä, kuten geometrisia operaatioita (ANGLE) (Koedinger 1992), koeasetelman rakentamista (ALEL) (Lehtinen 1997), teknistä ongelmanratkaisua (SHERLOCK) (Lesgold, Lajoie, Bunzo, \& Eggan 1992) tai matemaattisten sanallisten tehtävien ratkaisun visualisointia (HERON) (Reusser 1993).

Ympäristön representaatioiden ${ }^{17}$ ja erityisesti moninaisten samaan tehtävään tai sisältöön liittyvien representaatioiden avulla voidaan tarkasteltava ilmiö (vrt. edellä esim. verkkokeskustelu, geometrinen ongelmanratkaisu, tilastollinen koeasetelma, teknisen asiantuntemuksen harjoittaminen tai sanalliset tehtävät) esittää monella eri tavalla, mm. ilmiö voidaan kuvata tietystä perspektiivistä, ilmiötä voidaan tarkastella eri tarkkuuksilla (vrt. kartan mittakaava), ilmiö voidaan esittää käyttäen yhtä tai useata erilaista informaation esittämisen modaliteettiä (teksti, animaatio, diagrammi jne.), ilmiöstä voidaan nostaa joitain erityisiä piirteitä esille ja ilmiön kompleksisuutta voidaan hallita, esimerkiksi rajaamalla tai painottamalla haluttuja seikkoja (de Jong et al. 1998). 
Moninaisia representaatioita voidaan käyttää monipuolisesti oppimisen tukemisessa, esim. seuraavassa on neljä tilannetta, joissa moninaisia representaatioita on käytetty oppimisen ja opetuksen tutkimuksessa (Lesgold 1998):

Useita analogioita käyttämällä voidaan kuvata yhtä ilmiötä usealta eri näkökannalta, käytettyjen analogioiden mukaisesti. Spiron ja kumppaneiden (Spiro \& Jehng 1990) kehittämää kognitiivisen joustavuuden teoriaa ${ }^{18}$ on sovellettu $\mathrm{mm}$. taidesuuntauksen piirteiden oppimisessa (Balcytiene 1996).

\section{Monitasoisen tietämyksen esittämistämoninaisilla representaatioilla voidaan hyödyntää esimerkiksi läk̈ketieteellisessä diagnostiikassa ja lääkäriksi kou- luttamisessa. Boshuizenin et al. tutkimuksien mu- kaan perehtyessään lääketieteelliseen ilmiöön joutuvat opiskelijat hyödyntämään usean eri tie- teenalan tietämystä ja yhdistämään niistä esim. todennäköisin diagnoosi. Yksittäisen tieteenalan tietämyksen avulla ilmiö ei ole tarkasti selitettä- vissä (Boshuizen \& van de Wiel 1998).}

Kompleksinen tekemällä oppiminen on osoittautunut toimivaksi pedagogiseksi malliksi kompleksista asiantuntemusta vaativien tehtävien harjoittamisen ja oppimisen tukemisessa. SHERLOCKohjatussa harjoitteluympäristössä teknikot suorittavat elektronisten piirikorttien virheenetsintää. Asiantuntijan tietämyksestä on muodostettu virheenetsinnän kognitiivinen malli, jota kuvataan interaktiivisella graafisella esityksellä. Tällaisten moninaisten representaatioiden ja työtehtävän strategisella ohjaamisella ${ }^{19}$ voi harjoittelija saavuttaa huomattavaa kehitystä verrattuna työssä tapahtuvaan oppimiseen. SHERLOCK-ympäristössä voidaan mm. harjoitella työssä harvoin esiintyviä virheitä, visualisoida virheiden hakustrategioita, ohjata työskentelyä ns. älykään tutorin ja mallitetun asiantuntijan tietotaidon avulla (Lesgold et al. 1992; Levonen 1993; Levonen \& Lesgold 1993, August).

\section{Kokemuksellisenjaabstraktintietämyksen integrointi} on keskeinen koulutuksen haaste: Useissa nykyyhteiskunnan työtehtävissä, esim. Internet- tai uusmediaohjelmointi, kokemuksellisen tietotaidon merkitys on korostunut. Kykyä luoda tieto- yhteiskunnan informaatio-objekteja, kuten webbi portaaleja $^{20}$, ja kykyä hallita niiden käyttöä ja ylläpitoa arvostetaan nykypäivänä. Useat hankkivat uusmedian tietotaidon koulutusorganisaatioiden ulkopuolella ja omaehtoisesti. Yhteiskunnan haasteeksi on muodostunut luoda sekä tehtävistä ("bottom-up"), että teoriasta ("topdown") nousevia uusia oppimisen ja opetuksen ratkaisuja, joissa tavoitteena on kehittää vuorovaikutusta konkreettisen, kokemuksellisen tiedon ja koulutuksen tuottaman abstraktin, teoreettisen tiedon välillä (Lesgold 1998).

\section{Teknologian kanssa tai sen vaikutuksesta oppiminen}

Oppimisympäristössä oppiminen ja opiskelu voi olla hyvin monimuotoista. Oppija voi perehtyä sisältöalueeseen, suorittaa harjoituksia, seurata ja osallistua keskusteluun, hän voi suunnitella ja arvioida tai osallistua muuten aktiivisesti virtuaalisen oppimisyhteisön toimintaan. Salomon nosti esille keskeisen kysymyksen, millainen vaikutus oppimiseen on työskentelyllä teknologian kanssa ('with') ja toisaalta, miten opitaan teknologian vaikutuksesta ('of') (Salomon, Perkins, \& Globerson 1991):

Teknologian kanssa oppiminen (with) tapahtuu tietokoneiden ja -verkkojen välityksellä (se on esimerkiksi viestien välittämistä ja kommentointia) ja toiminnassa hyödynnetään erityisesti ympäristön representaatioita (kuvia, ikoneja, diagrammeja jne.). Diagrammien ja kuvien avulla voidaan vaikuttaa ajatteluun ja oppimiseen. Tästä on löydetty tutkimuksissa mm. seuraavia tuloksia (Larkin \& Simon 1987; Mayer 1989): Kuvassa voidaan esittää kaikki olennainen tieto kerralla ja olennainen tieto on helposti löydettävissä, kuva voi olla (vrt. esimerkiksi ikonien käyttö tietokoneen ohjelmissa), kuvaa voidaan käyttää kohdentamaan lukijan huomio selittävään informaatioon tekstissä ja kuvaa voidaan käyttää tukemaan informaation uudelleenorganisointia mielekkäiksi mentaalisiksi malleiksi.

Oppimisessa teknologian vaikutuksesta (of) on kysymys siirtovaikutuksesta, missä tietokoneiden välityksellä työskentelystä siirrytään todellisiin ti- 
lanteisiin (esimerkiksi verkkokeskustelussa vs. neuvottelussa keskustelu ja kommentointi). Onko esimerkiksi vuorovaikutteisella työskentelyn "seurauksena kognitiivinen "oheistuote"21 vaikutus oppijaan, kun hän työskentelee erillään tietokoneista?

\section{Kollaboratiivinen verkko- o p p i m is y m päris tö}

Kollaboratiivisella ${ }^{22}$ oppimisympäristöllä pyritään tukemaan oppimis- ja opiskelutoimintaa tarjoamalla osallistujille välineitä kommunikaatioon, erilaiseen vuorovaikutukseen ja aktiviteetteihin (Dillenbourg, Baker, Blaye, \& O’Malley 1996). Kollaboratiivinen oppimisympäristö kommunikoi myös omalla toimintakulttuurillaan ja tavoillaan, joilla ko. ympäristössä pyritään toteuttamaan oppimistoimintaa.

Seuraavaksi tarkastelen lähemmin argumentoinnin avulla suoritettavaa kollaboratiivista oppimista tukemaan rakennettua Belvedere-oppimis- ympäristöä. Verkkoperustainen Belvedere-ympäristö tarjoaa käyttäjälle välineitä kollaboratiiviseen argumenttien konkretisointiin ja visualisointiin (Suthers, Wainer, Connolly, \& Paolucci 1995). Ympäristön käyttäjä voi tunnistaa ja luoda argumenttien osia, elementtejä (data, hypoteesi ja periaate) ja määrittää suhteita eri elementtien välille (tukee, vastustaa, ja) (ks. kuva 1). Argumentointiprosessia Belvedere tukee luomalla visuaalisen argumenttirakenteen, joka muuttuu järjestelmään syötettyjen argumenttielementtien ja -suhteiden myötä. Belvedere tukee myös yhteistoiminnallista oppimista: Verkkotyöskentelyn kautta ympäristön käyttäjät luovat yhteisen näkymän käsiteltävään alueeseen. Yhteistoiminnallisella työskentelyllä ja argumentoinnilla on tavoitteena sekä kehittää sisältöalueen tietämystä että ylläpitää osallistujien motivaatiota tarkastella kysymyksessä olevaa ilmiötä.

Suomessa Belvedere -ympäristöä (ks. Kuva 1) on ensimmäisen kerran käytetty Tietotekniikan opetuskäytön tutkimus- ja kehittämisyksikössä $(\mathrm{TOTY})^{23}$ toteutetussa tutkimuksessa keväällä

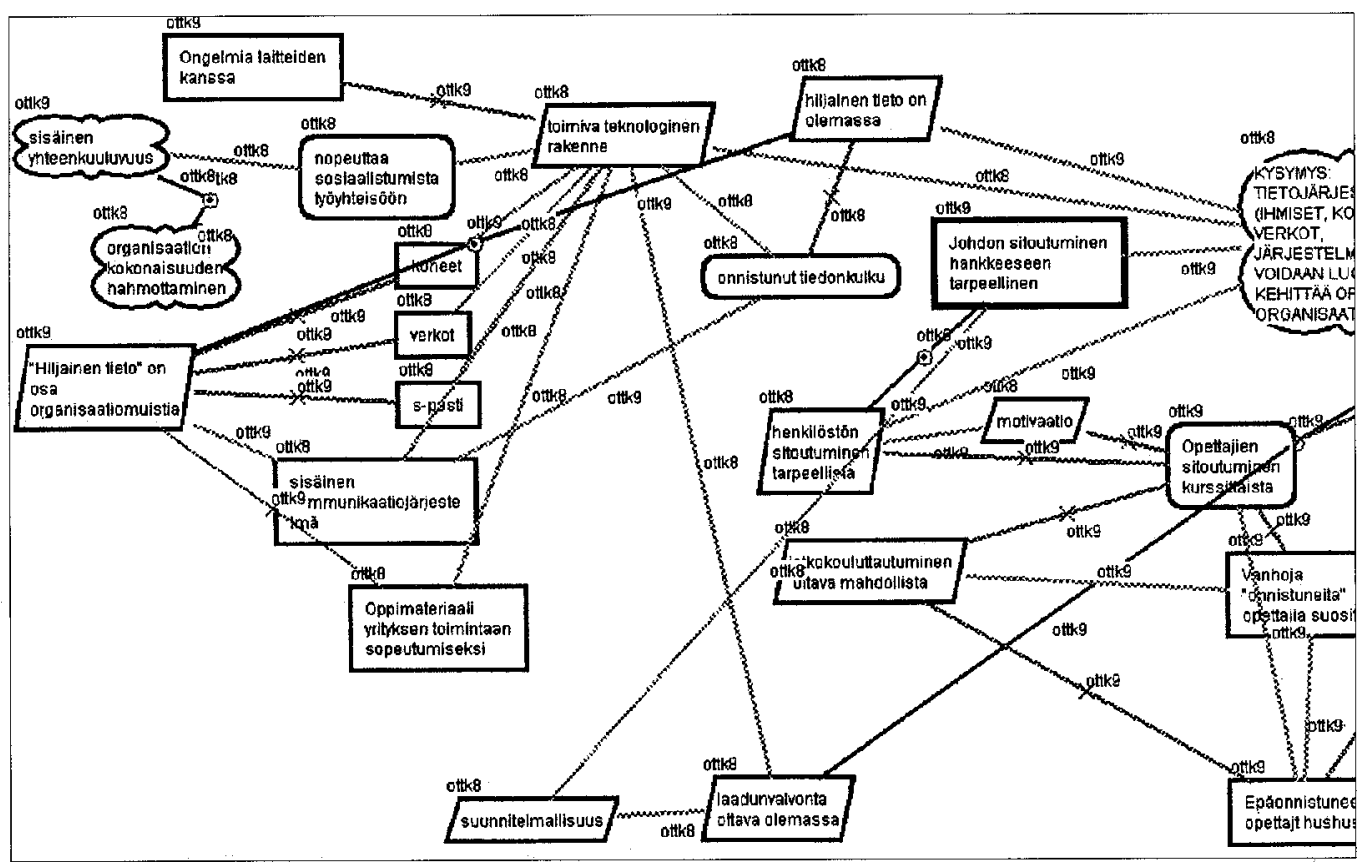

Kuva 1. Belvedere argumentointiympäristö kollaboratiivisessa oppimisessa 
1999 (Levonen 1999a). Kokeilu järjestettiin osana TAO-seminaarin ja yritysvierailujen päätösjaksoa. Opiskelijat toimivat kahdessa ryhmässä eri tietokoneluokissa luoden virtuaalisia argumenttirakenteita Belvedere-ympäristössä. Eksploratiivisen tutkimuksen tavoitteina oli $\mathrm{mm}$. selvittää miten opiskelijat kokivat ko. argumentointiympäristön ja miten ympäristö soveltuisi yliopisto-opetukseen (Levonen 1999b).

Ryhmähaastattelussa opiskelijat kuvasivat Belvederen käyttökokemuksia positiiviseksi ja rikkaaksi kokemukseksi. Ympäristö tuki opiskelijan tiedon esittämistä ja kommunikaatiota ja auttoi opiskelijoita tuomaan esille olennaisia asioita käsiteltävästä aiheesta (Levonen 1999b).

Opiskelijoiden kuvaamat kokemukset näyttävät tukevan Belvedere-ympäristön suunnittelun keskeistä tavoitetta: Tieteellisen ajattelun tukeminen. Tieteellisen ajattelun kehittymisessä on havaittu useita ongelmia, joiden kehittymistä Belvedere pyrkii tukemaan (Suthers et al. 1995):

1 vaikeus tunnistaa tieteellisten teorioiden ja argumenttien implisiittisiä (epäsuoria) suhteita

$1 \quad$ vaikeus seurata olennaisia elementtejä kompleksissa väittelyssä ja argumentoinnis$\mathrm{sa}$

1 puutteelliset kriteerit arvioida tieteellistä argumentointia

1 vaillinainen sisältöalueen tietämys

1 puuttuva sisäinen motivaatio, vrt. asiantuntija

Belvedere-ympäristön haasteeksi koettiin visuaalisen ympäristön ominaisuus, se, että useat eri näkökulmat olivat esillä samanaikaisesti ja lopullisia ratkaisuja oli vaikea saavuttaa. Graafisten argumenttien luominen ja argumenttien seuraaminen koettiin toisinaan vaikeaksi (Levonen 1999b). Vastaavia tuloksia visuaalisen argumentointiympäristön käytön ongelmista on esittänyt Rittel (1972, viitattu teoksessa (Buckingham Shum, MacLean, Bellotti, \& Hammond in press):

1 tehtävää on vaikea määrittää siten, että kaikilla on yhtäläinen käsitys ratkaistavasta ongelmasta

1 ei ole selkeitä sääntöjä päättää tehtävä

1 ei parempaa tai heikompaa ratkaisua, ei oikeata tai väärää ratkaisua

1 ei ole objektiivisia menestyksen mittareita

1 vaatii useita ratkaisukertoja, kaikki yritykset vaikuttavat

1 ei ole annettua vaihtoehtoista ratkaisua, ne on itse löydettävä

1 vaatii kompleksista päätöksentekoa siitä, mil lä abstraktiotasolla ongelmaa käsitellään

1 usein toimintaan liittyy voimakkaat moraaliset, poliittiset tai professionaaliset näkökulmat, joita on vaikea formalisoida

Belvedere-ympäristön käytön kokemukset olivat rohkaisevia ja antoivat runsaasti viitteitä hajautetun kollaboratiivisen oppimisympäristön mahdollisuuksista yliopisto-opetuksessa: Opiskelijat kokivat toimintaprosessin ja ympäristön tukevan oman ajattelun kehittymistä, mikä onkin tieteellisen ajattelun kehittymisen näkökulmasta olennaista.

\section{Takaisin tulevaisuuteen?}

Uusien oppimisympäristöjen globaalit markkinat ovat kehittymässä. Viitteitä tulevasta oppimistoiminnan ${ }^{24}$ kehityksestä on jo nähtävissä $\mathrm{mm}$. uusien yliopisto-yritys ${ }^{25}$ yhteenliittymien muodossa. Mielenkiintoinen kysymys onkin pohtia, millaisia polkuja valitsemme oppimiselle tulevaisuudessa.

\section{Oppimisympäristöjen ja verkkopedagogi $i$ an "standardoitumisen" polku}

Uusien oppimisympäristöjen nopea kehittyminen kokeilevista ja innovatiivisista kehittämishankkeista kaupallisiksi "verkko-oppimisalustoiksi" 26 on yksi osoitus uuden oppimisteollisuuden markkinoiden kehittymisestä, eli yritysten ja organisaatioiden tarpeesta toteuttaa koulutusta verkko-oppimisympäristöjen avulla. Yhä laajempi osa organisaation normaalista kommunikaatiosta voidaan toteuttaa verkossa. Informaation välittäminen ja uusien vuorovaikutusmahdol- 
lisuuksien luominen voidaan valjastaa tukemaan koko organisaation kehittymistä. Verkko-oppimisalusta voidaan räätälöidä organisaation koulutustarpeen mukaisesti. Ympäristöön voidaan tarvittaessa yhdistää sekä moninaiset mahdollisuudet kommunikointiin ja opetuksen toteuttamiseen että opiskelijoiden opintojen seurantaan. Palveluun voidaan liittää organisaation oppimiskulttuuriin liittyvien toimintojen ohjaaminen, kuten oppimisympäristön käyttöönotto, hyvien oppimis- ja koulutuskäytäntöjen luominen, käytön seuranta ja kehittäminen. Ympäristöä ylläpidetään Internetin välityksellä, jolloin satsaukset omien laitteiden tai ylläpidon organisoinnin sijaan voidaan kohdentaa yrityksille, jotka järjestävät ko. oppimisympäristöpalvelun ${ }^{27}$. On odotettavissa, että verkko-opetuksen ja -oppimisen toteuttamisen ja -hallinnoinnin ${ }^{28} \mathrm{ke}$ hittyminen ja "standardoituminen" oppimisen tukijärjestelmiksi ${ }^{29}$ tukee ympäristöjen kehittymistä helppokäyttöisemmiksi ja samalla ympäristöt tulevat yhä laajempaan käyttöön. Sisällöntuotanto oppimisympäristöihin helpottuu standardien oppimateriaalien, oppimisympäristöjen ja niiden liittymien johdosta.

\section{Oppimisympäristöjen ja verkkopedagogikan "moninaistumisen" polku}

Edellä kuvattu oppimisympäristöjen laaja-alainen kehittyminen ja kaupallistuminen ei olisi mahdollista ilman kehittäjiä, innovaatioita, ja Internetin "jaettua kognitiota". Useat oppimisympäristöissä käytössä olevat kommunikaation välineet on luotu tutkimus- ja kehittämishankkeissa tai yksittäisten harrastajien iltapuhteina. Internetin "jaetun kognition" voimakkain osoitus lienee "Suomalainen" ja globaali Linux-käyttöjärjestelmä, joka on noussut harvojen harrastajien puuhastelusta maailmanlaajuiseksi tuotteeksi. Vastaavasti uusien oppimisympäristöjen kehittäminen ja pedagogisten kokemusten vaihtaminen jatkuu Internetissä $\ddot{a}^{30}$. "Vapaasta" Internetistä muodostuu avoimen ja moninaisen pedagogisen kehittämis- ja tutkimustoiminnan viimeinen saareke.

Uusien oppimisympäristöjen ja Internetin ope- tuskäytön lyhyen, mutta nopean kehittymisen yksi opetus on ollut ennakoimattomuus. Se lienee vastaisuudessakin ainoa ennakoitava seikka.

\section{Lähteet}

BALCYTIENE, A. (1996) Using hypertext to read and reason. Joensuu: Faculty of Education, University of Joensuu.

BoshuIZEN, H. P. A., \& van de Wiel, M. W. J. (1998) Using multiple representations in medicine: How students struggle with them. In M. V. Someren, P. Reimann, H. Boshuizen, \& T. d. Jong (Toim.), Learning with multiple representations (s. 237262). Oxford: Elsevier Science.

BUCKINGHAM Shum, S. J., MacLean, A., Bellotti, V. M E., \& Hammond, N. V. (in press) Graphical argumentation and design cognition. Human-Computer Interaction.

COLLIS, B. (2000) WWW-Based Rapid Prototyping as a Strategy for Training University Faculty to Teach WWW-Based Courses. In E. Khan (Toim.), Web-based training. Englewood Cliffs, NJ: Educational Technology Publications.

de JONG, T., Ainsworth, S., Dobson, M., van der Hulst, A., Levonen, J., Reimann, P., Sime, J.-A., van Someren, M., Spada, H., \& Swaak, J. (1998) Acquiring knowledge in science and mathematics: the use of multiple representations in technology based learning environments. In M. V. Someren, P. Reimann, H. Boshuizen, \& T. d. Jong (Toim.), Learning with multiple representations (s. 9-41). Oxford: Elsevier Science

DILlENBOURG, P., Baker, M., Blaye, A., \& O’Malley, C. (1996) The evolution of research on collaborative learning. In E. Spada \& P. Reiman (Toim.), Learning in humans and machines: Towards an interdisciplinary learning science. (s. 189-211). Oxford: Elsevier

DILlON, A. (1996) Myths, misconceptions, and an alternative perspective on information usage and the electronic medium. In J.-F. Rouet, J. J. Levonen, A. Dillon, \& R. Spiro (Toim.), Hypertext and Cognition (s. 25-42). Mahwah, NJ: Lawrence Erlbaum Associates.

HIETALA, P., Majaranta, P., Niemirepo, T., Ovaska, S., \& Salonen, J. (1997). WWW-pohjainen ryhmäkommentointi yliopisto-opetuksen osana (Raportti B-1997-9). Tampere: Tietojenkäsittelyopin laitos, Tampereen yliopisto.

KOEDINGER, K. R. (1992) Emergent properties and structural constraints: Advantages of diagrammatic representations for reasoning and learning. In N. H. Narayanan (Toim.), Working Notes of the AAAI Spring Symposium on Reasoning with Diagrammatic Representations (s. 154-159). San Francisco, CA: Stanford University

LARKIN, J. H., \& Simon, H. A. (1987) Why a diagram is (sometimes) worth ten thousand words. Cognitive Science, 11, 65-99

LEHTINEN, E. (1997) Tietoyhteiskunnan haasteet ja 
mahdollisuudet oppimiselle. In E. Lehtinen (Toim.), Verkkopedagogiikka (s. 12-40). Helsinki: Edita.

LESGOLD, A. (1998) Multiple representations and their implications for learning. In M. W. v. Someren, P. Reimann, H. P. A. Boshuizen, \& T. d. Jong (Toim.), Learning with multiple representations. Amsterdam: Pergamon.

LESGOLD, A., Lajoie, S., Bunzo, M., \& Eggan, G. (1992) SHERLOCK: A coached practice environment for an electronic troubleshooting job. In J. H. Larkin \& R. W. Chabay (Toim.), Computer-assisted instruction and intelligent tutoring systems: shared goals and complementary approaches (s. 201238). Hillsdale, NJ: Lawrence Erlbaum Associates.

LEVONEN, J. (1999a). Learning with graphical explanations. Paper presented at The Belvedere Colloquim at the Open University of the Netherlands, August 30, 1999, Heerlen, the Netherlands.

LEVONEN, J. (1999b). Oppiminen ja oppimisympäristön moninaiset representaatiot, Paperi esitetty Tietotekniikan opetuskäytön tutkimus- ja kehittämisyksikön, TOTY:n 10-vuotisjuhlassa 9.12.1999, Kasvatustieteiden tiedekunta, Joensuun yliopisto.

LEVONEN, J. J. (1993) SHERLOCK and BELVEDERE Training and Learning in a Computer Environment: Studies of Two Systems and Two Environments for Learning. Presentation at the III European Congress of Psychology. Tampere.

LEVONEN, J. J., \& Lesgold, A. M. (1993, August) Visual reasoning in coached practice environment: $\mathrm{Vi}$ sual meaning making in SHERLOCK. In R. Cox, M. Petre, P. Brna, \& J. Lee (Toim.), Proceedings of the Workshop on Graphical Representations, Reasoning and Communication at the AI-ED 93 World Conference on Artificial Intelligence in Education (s. 21-23). August 25th 1993. Edinburgh, Scotland: The University of Edinburgh.

LEVONEN, J. J., \& Tuononen, K. (1998, Huhtikuu). Tietoverkot peruskoulun oppilaiden välineenä: Tapauskuvaus HyperNewsin ja Linuxin käytöstä koulussa. Paper presented at the Interaktiivinen teknologia koulutuksessa (ITK-98). Tuntematon tietoyhteiskunta, 17.-18.4.1998. Hämeenlinna

LEVONEN, J. J., Tuononen, K., \& Laine, J. (1997, November). Project work and World Wide Webbased collaboration: A case of HyperNews and Linux in schools. Paper presented at the The Second Symposium on Learning and Instruction (JULIS'97), November 7-8, 1997. University of Joensuu, Finland.

Manninen, J., \& Pesonen, S. (1997) Uudet oppimisympäristöt. Aikuiskasvatus(4), 267-274

MAYER, R. E. (1989) Systematic thinking fostered by illustrations in scientific text. Journal of Educational Psychology, 81(2), 240-246.

McHENRY, B. A. (1999) New features for learning management systems. ALN Magazine (http:// www.aln.org/), 3(2), http://www.aln.org/alnweb/ magazine/Vol3_issue2/McHenry.htm

PALMER, S. E. (1978) Fundamental aspects of cognitive representation. In E. Rosch \& B. B. Lloyd (Toim.), Cognition and categorization (s. 259-
303). Hillsdale, NJ: Erlbaum.

REUSSER, K. (1993) Tutoring systems and pedagogical theory: Representational tools for understanding, planning, and reflection in problemsolving. In S. Lajoie \& S. Derry (Toim.), Computers as cognitive tools (s. 143-177). Hillsdale, NJ: Lawrence Erlbaum.

ROUET, J.-F., \& Levonen, J. (1996) Studying and learning with nonlinear documents: Empirical studies and their implications. In J.-F. Rouet, J. J. Levonen, A. Dillon, \& R. Spiro (Toim.), Hypertext and Cognition (s. 9-23). Mahvah, NJ: Lawrence Erlbaum.

SALOMON, G., Perkins, D. N., \& Globerson, T. (1991) Partners in cognition: Extending human intelligence with intelligent technologies. Educational Researcher, 20(3), 2-9.

SCARDAMALIA, M., Bereiter, C., Brett, C., Burtis, P. J., Calhoun, C., \& Smith Lea, N. (1992) Educational applications of a networked communal database. Interactive Learning Environments, 2(1), $45-71$.

SINKO, M., \& Lehtinen, E. (1998) Bitit ja pedagogiikka. Jyväskylä: Atena Kustannus

SPIRO, R. J., \& Jehng, J.-C. (1990) Cognitive flexibility and hypertext: Theory and technology for the nonlinear and multidimensional traversal of complex subject matter. In D. Nix \& R. Spiro (Toim.), Cognition, education, multimedia, edition (Vol. B, s. 163-205). Hillsdale, NJ: Lawrence Erlbaum Associates.

SUTHERS, D., Wainer, A., Connolly, J., \& Paolucci, M. (1995). Belvedere: Engaging Students in Critical Discussion of Science and Public Policy Issues. Paper presented at the Proceedings of the 7 th World Conference on Artificial Intelligence in Education (AI-ED 95), August 16-19, 1995, Washington, DC

van SOMEREN, M. W., Reimann, P., Boshuizen, H. P. A., \& de Jong, T. (Toim.). (1998) Learning with multiple representations. Oxford: Elsevier.

\section{Viitteet}

1 Termillä "uusi", puhuttaessa uusista oppimisympäristöistä, tarkoitetaan viimeaikoina kehitettyjä vuorovaikutteisia ja usein tietokoneverkkoja hyödyntäviä oppimisen, opiskelun ja/ tai opetuksen tukemiseen kehitettyjä ympäristöjä. Synonyyminä käytetään usein myös termiä "moderni". Nähdäkseni termillä "uusi" ei ole merkittäviä oppimisympäristön laatua tai tyyliä (vrt avoin, verkkopohjainen, digitaalinen tai kontekstuaalinen oppimisympäristö) kuvaavia konnotaatioita kuin ajallisesti ajankohtainen, nykyaikainen tai viimeaikainen. Todettakoon, ettei "uusi" oppimisympäristö ole välttämättä "avoin" tai "suljettu" eikä päinvastoin, vrt. (Manninen \& Pesonen 1997), mm. oppimiskäsitys vaikuttaa olennaisesti siihen, miten uudessa oppimisympäristössä ohjataan oppimista (Lehtinen 1997).

2 Termillä "oppimisympäristö" tarkoitetaan konkreettisesti ympäristöä, jossa tietokone voi olla 
yhtenä osana em. Ympäristöä (esimerkiksi luokkahuone) ja/tai tietokoneen välityksellä näyttäytyvä virtuaalista oppimis- ja opiskeluympäristöä.

3 Termi "verkko-" on kontekstista irrotettuna monimerkityksellinen ja usein kontekstissakin sen merkitys voi olla moninainen tai epäselvä. Yleensä termillä "verkko-" tarkoitetaan toimintaa, jossa hyödynnetään tietokoneverkkoja (vrt. verkkopedagogiikka, verkko-oppimisympäristö). Tietokoneverkon näkökulmasta "verkko"-termi voi kuitenkin viitata (1) yleensä tietokoneiden verkkoa tai verkottumista (vrt. edellä kuvattu yleinen merkitys), (2) yksittäisen tietokoneen liittyminen verkkoon (esimerkiksi verkkoclient tai oppimisympäristö(verkko)client), (3) tiettyjen tietokoneiden verkkoa (esimerkiksi intranet yrityksen verkko-oppimisympäristönä), ja/tai (4) tietokoneverkon välityksellä tapahtuvan ja kollaboratiivisen toiminnan johdosta jaettua sisälsältöaluetta (vrt. "jaettu kognitio" tai verkostoituva oppiminen.

4 ks. http://www.webct.com/

5 ks. http://www.learningspace.com/

6 ks. http://www.lotus.com/

7 ks. http://www. firstclass.com/

8 ks.http://www.worldwidemart.com/scripts/ wwwboard.shtml

9 ks. http://www.hypernews.org/

10 ThULE (The Ultimate Learning Environment) oppimisympäristö on kehitetty TOTY-yksikössä Joensuun yliopistossa (ks. http://toty.joensuu.fi/ ja http://toty.joensuu.fi/thule/).

11 ks. http://proto.oulu.fi/

12 ks. http://www.mlab.uiah.fi/fle/fin_index.html

13 ks. http://www.kas.utu.fi/

14 Mukaan lukien vuorovaikutussuhteet, jotka näyttäytyvät oppijalle tietokoneen ja -verkkojen välityksellä, kuten usean oppijan, oppijan ja ryhmän sekä ryhmän ja ohjaajan välinen vuorovaikutus.

15 eli representoitu

16 Sanalla "multipleksi" viitataan eng. käsitteeseen "multiple representations", jolla tarkoitetaan useiden, moninaisten ja samaa oppimistavoitetta tukevien representaatioiden käyttämistä oppimisympäristössä, vrt. learning with multiple representations.

17 Representaatioilla, ks. (Palmer 1978), viitataan tavoiteltavien seikkojen edustamiseen kuvin, tekstein, tehtävien, jne. Edustettava asia voi olla osallistuminen pohtivaan keskusteluun, luettujen dokumenttien merkitseminen, jne. Mo- ninaisista representaatioista, ks. (van Someren, Reimann, Boshuizen, \& de Jong 1998).

18 eng. Cognitive Flexibility Theory

19 Ohjaamisella viitataan tässä ohjaamisen avulla harjoittamiseen (coached tai scaffolded practice)

20 Termi "portaali" (pääovi, portti) tarkoittaa WWW-sivua, jonka kautta yritys tai organisaatio tarjoaa kootusti palvelujaan.

21 "spin-off"

22 Kollaboratiivisella oppimisympäristöllä tarkoitetaan yhteistoiminnalliseen (collaborative ja/ tai cooperative) työskentelyyn suunniteltua verkko-oppimisympäristöä. Varhaisia kollaboratiivisia oppimisympäristöjä on esimerkiksi CSILE (Scardamalia et al. 1992). Nykyään useissa kaupallisissa oppimisympäristöissä on nähtävissä kollaboraatiota tukevia välineitä, kuten viestien välittäminen, kommentointi, online keskustelu (esimerkiksi chat), yhteiset työskentelyalueet (esimerkiksi whiteboard), projekti ja/tai ryhmätilat, sähköposti, jne.

23 Tietotekniikan oppimiskäytön tutkimus- ja kehittämisyksikkö TOTY sijaitsee soveltavan kasvatustieteen laitoksella Joensuun yliopistossa.

24 vrt. "learnaativity", ks. http:// www.learnativity.com/

25 vrt. esimerkiksi http://www.unext.com/ ja http:// www.cardean.com/

26 englanniksi Learning platform

27 ks. esimerkiksi Suomessa http://www.lcprof.com/ tai http://www.soneraplaza.fi/experience/ ja maa ilmalla mm. http://www.webct.com/, http:// www.learningspace.com/ tai http:// company.blackboard.net/

28 ks. Instructional Managemet Systems (IMS) http:/ /www.imsproject.org/

29 vrt. Learning Management Systems, ks. (Mc Henry 1999)

30 ks. http://www. gnacademy.org/

Artikkeli saapui toimitukseen 26.4.2000. Se hyväksyttiin julkaistavaksi lausuntojen jälkeen uudelleen työstettynä 3.5. 